\title{
Domestic Macroeconomic Adjustment to Oil Price Shocks Under Different Exchange Rate Regimes in Malaysia
}

\author{
FUMITAKA FURUOKA \\ WONG HOCK TSEN \\ CHONG HUI ING \\ School of Business and Economics \\ Universiti Malaysia Sabah \\ TING SIEW KING \\ School of Business and Economics \\ Universiti Technology MARA
}

\begin{abstract}
This study examined the insulation properties of flexible exchange rate regime and fixed exchange rate regime in response to the oil price shocks in Malaysia. A monthly time series data for the period 19802005 was used to examine whether the response of output, exchange rate and price levels to the oil price shocks were different across the exchange rate regimes. For this purpose, this study employed the structural vector autoregressive model. Empirical results indicated that the short-run output responses to the oil price shocks are smoother under the flexible exchange rate regime compared to the situation under the fixed exchange rate regime.
\end{abstract}

Keywords: Exchange rate regimes; oil price; structural VAR modeling; Malaysia.

\begin{abstract}
ABSTRAK
Kajian ini mengkaji ciri-ciri penyingkiran sistem kadar pertukaran wang boleh ubah dan sistem kadar pertukaran tetap dalam tindak balas terhadap kejutan harga minyak di Malaysia. Data siri masa bulanan untuk tempoh 1980-2005 digunakan untuk menguji sama ada tindak balas output, kadar pertukaran wang dan tingkat harga terhadap kejutan harga minyak berbeza antara sistem kadar pertukaran wang. Untuk tujuan ini, kajian ini mengunakan model "Structural Vector Autoregressive". Keputusan empirikal menunjukkan bahawa tindak balas output jangka pendek terhadap kejutan harga minyak adalah lebih licin di bawah sistem kadar pertukaran wang boleh ubah berbanding dengan keadaan di bawah sistem kadar pertukaran wang tetap.
\end{abstract}

\section{INTRODUCTION}

Economic globalisation with its intensified cross border flow of goods and services has far reaching effects on large and small, developed and developing countries. This paper focuses on Malaysia. Malaysia has a small trade dependent economy with a high degree of foreign presence in both the production and financial sectors, which makes the country dependent on the trends 
and developments in the global economy. Thus, unexpected changes in the global economic landscape that originate outside of Malaysia are rapidly transmitted into the country and affect its economic situation. One of the alternatives to mitigate the negative consequences of some trends in the global economy which occur from time to time, for example economic shocks, is the implementation of the flexible exchange rate regime as suggested by Friedman (1953).

In the early 1950s, Friedman (1953) maintained that the flexible exchange rate regime allows a smoother adjustment of macroeconomic variables in responses to external economic shocks because the nominal and the real exchange rates would be more easily adjustable under the flexible exchange rate regime. This would allow a speedier adjustment in relative prices of foreign and domestic goods, and a better balancing in terms of supply of goods. On the other hand, under the fixed rate regime, price adjustments in response to external shock would work much slower because of the so-called "stickiness" of the price adjustment process. When the nominal exchange rate is fixed, the adjustment process has to be implemented through changes in nominal prices, including wages. Due to the hindering features of price stickiness, the flexible exchange rate regime is more preferable than the fixed rate regime to protect and insulate the domestic economy from the negative effects of foreign shocks.

This paper aims to analyse insulating properties of the flexible exchange rate regime compared to the fixed exchange rate regime in the case of the oil price shocks. First of all, this study compared the adjustment process of exchange rates, price levels, and output in response to the oil price shocks under two different exchange rate regimes. Secondly, this study measured the relative importance of the oil price shocks in explaining the overall variance of exchange rates, price levels, and output.

This paper consists of six sections. Following this introduction, section two offers a brief review of relevant study literature. Section three outlines the methodology and econometric framework employed in the study. Section four discusses the data employed in this research while section five reports the empirical results. Finally, section six offers a brief summary of the study's findings.

\section{LITERATURE REVIEW}

Numerous research studies have been devoted to examining the effect of the oil price shocks on the macroeconomic variables. Also, researchers paid close attention to the issue of feasibility of implementing the flexible exchange rate regime as a tool to insulate domestic macroeconomic variables from the external shocks.

Some of these empirical studies focused on stability and asymmetry effects in the relationship between the oil price shocks and macroeconomic variables. Studies by Hamilton (1983), Burbidge and Harrison (1984), and Gisser and Goodwin (1986) reported a negative linear relationship between the oil prices and economic activity, and associated the oil price shock with a reduction in economic activity. However, the findings of these studies were not supported by the inquiries where data sets were extended to include the oil price crisis in 1985. Instead of a symmetric specification relationship between the oil prices and economic activity some research studies focused on fluctuations of the oil prices. For example, papers by Mork (1989), and Mork, Olsen, and Mysen (1994) distinguished between the negative and positive oil price shocks. They found a significant relationship between the positive shocks and output growth. However, no such relationship was found between the negative shocks and output growth.

Hooker (1996) argued that the relationship between the oil prices and output, including the asymmetric relation, only existed for the pre1970s data sets but not for the post-1970s data sets. Since Hooker (1996) published his paper, alternative statistical definitions and specifications of oil price shock series were put forward in a number of academic inquiries into the topic. Some studies reestablished the statistical relationship between the oil price shocks and national GDP (Ferderer, 1996; Guo \& Kliesen, 2005; Hamilton, 1996; Lee, Ni, \& Ratti, 1995). Hamilton (1996) found that major oil price movements from 1948 
to 1985 , when the oil prices collapsed, had been caused by price increases. However since then the process have been affected by higher volatility, and was subjected to greater positive and negative price swings. Hamilton (1996) suggested that spending decisions by consumers and firms were based on the differences in the current price of oil and maximum value price of oil in previous four quarters, or, in other words, by the "net oil price increases".

Lee Ni et al. (1995) argued that consumer behaviour may be shaped by how they perceived forthcoming changes. Considering the fact that there have been large positive and negative changes in economy since the oil price collapse in 1985, Ferderer (1996) argued that consumer behaviour is based on the recent changes in oil price. Uncertainty in oil price fluctuation is important to consider as this may lead to a reduced investment activity. Monthly standard deviation in oil price is established through a daily spot check of the oil price. Instead of calculating the volatility of the current oil prices, Guo and Kliesen (2005) measured the volatility of future oil prices in order to establish the oil price series that are based on daily reported crude oil future prices, or the realised oil price variance.

Some studies examined the role of exchange rate regimes in insulating the domestic economies from the negative effect of economic disturbances originating abroad. Empirical research by Gerlach (1988) and Baxter and Stockman (1989) focused on the correlation and volatility in the data to analyse the influence of the exchange rate regimes on macroeconomic variables. The main difficultly of investigating standard deviation and correlation of data is the possible incongruity in interpretation of results. For example, increases in national income or a degree of openness of an economy may interfere with the interpretation of results.

To overcome this problem, Sims (1980), and Blanchard and Quah (1989) proposed to apply the VAR model to look at the responses of a system to macroeconomic variables shocks. A similar method was adopted by several other studies (Bayoumi \& Eichengreen, 1994; Genberg, Salemi, \& Swoboda, 1987; Hutchison \& Walsh, 1992; Lastrapes \& Koray, 1990; Robertson \& Wickens, 1997; Sissoko \& Dibooglu, 2006). Some studies on the topic (Broda, 2004; Hoffmaister, Roldós, \& Wickham, 1997) used panel data method with VAR model. On the other hand, a number of studies (Edwards \& Levy Yeyati, 2005; Ramcharan, 2005) applied regression model based on the panel data methods instead of the VAR model to investigate the role of exchange rates in insulating economies from foreign-originated shocks.

A number of previous studies produced evidence that oil price shocks have a significant impact on macroeconomic variables in Malaysia. Thus, Cunado and Gracia (2005) reported a significant relationship between the oil prices and the price index in the short-run. A study by Chua, Dibooglu, and Sharma (1999) showed that oil price shocks do have an effect on Malaysian outputs. A research by Abeysinghe (2001) concluded that oil net exporters, such as Malaysia, cannot escape neither positive nor negative effects of the high oil prices due to the indirect effects on their economies by trade partners. Therefore, oil price shocks would yield a negative impact on output in these countries. A recent empirical study by Mansor (2003) examined the role of exchange rates on the transmission process of external shocks in the case of Malaysia. Mansor (2003) indicated that the foreign price levels and output do influence the variations in exchange rate. These variations, in turn, influence the domestic variables including output, price levels, and money supply. Thus, the study established exchange rate regimes as channels of shock transmissions from a foreign to the domestic economy.

\section{METHODOLOGY}

In this study, the data series were first tested for unit roots using the augmented Dickey-Fuller unit root test (Dickey \& Fuller, 1981). The test's critical values were based on MacKinnon's (1996) calculation, while the optimal lag lengths were determined by the Akaike Information Criterion. The Johansen (1991) test then examined whether a group of non-stationary variables are cointegrated by the means of the trace and maximum eigenvalue tests. 
In order to examine the insulating properties of the flexible exchange rate regime, the VAR model was applied. The VAR model makes use of the impulse response and the variance decomposition to analyse various forms of innovations. The impulse response method allows looking at the response patterns or the adjustment process of domestic variables to the oil price shocks and considers the asymmetric effect in the responses to the positive and negative oil price shocks. Next, the variance decomposition measured the relative importance of the oil price shocks in explaining the overall variance of domestic variables.

The structural VAR model can be expressed as,

$A(L) z_{t}=e_{t}$

where $z_{t}$ and $e_{t}$ represent $n \times 1$ vector which comprises $z_{t}^{\prime}=\left(\Delta o i l_{t}, \Delta y_{t}, \Delta r e r_{t}, \Delta p_{t}\right), e_{t}^{\prime}=$ $\left(e_{t}^{\text {oil }}, e_{t}^{y}, e_{t}^{r e r}, e_{t}^{p}\right), E\left(e_{t} e_{t}^{\prime}\right)=\Sigma_{e}$ and $\Sigma_{e}$ $=P P^{\prime} . A(L)$ is a matrix polynomial in the lag operator $L$, where $A(L)=A_{0}-A_{1} L-A_{2} L^{2}-\ldots$ and $L^{k} z_{t}=z_{t-k}$.

Equation (1) can be rewritten as a moving average representation of a structural model, in which the endogenous variables are expressed in terms of the current and past structural shocks, as follows:

$z_{t}=C(L) e_{t}$

where $C(L)=A(L)^{-1}$.

The structural VAR model above is recovered from the reduced form of the VAR model by multiplying both sides of the equation (2) by $\mathrm{A}_{0}^{-1}$ to get the following equation,

$B(L) z_{t}=\mu_{t}$

where $B(L)$ is a matrix polynomial in the lag operator $L ; E\left(u_{t} u_{t}^{\prime}\right)=\sum_{u} ; B(L)$ is defined as $B(L)$ $=B_{0}-B_{1} L-B_{2} L^{2}-\ldots$ in which $B(L)=B_{0}=\mathrm{I}$.

The structural VAR model can be identified using restrictions on covariance matrix of structural shocks, $\Sigma_{e}$, and the matrix of long-run multipliers, $A(1)$. The structural shocks were assumed to be uncorrelated in the case when $\sum_{e}$ is a diagonal matrix. The exogeneity of the oil prices to the remaining variables implied that the first row of the matrix polynomial $A(1)$ takes the form $\left(a_{11}(1) \quad 0 \quad 0 \quad 0\right)$. Three additional assumptions on the third element in the second row, and the fourth element in the third and the fourth rows implied that the particular structural innovation does not have a long-run effect on the level of the endogenous variable, which is in-line with Broda (2004). Therefore, the zero restrictions which were imposed on the long-run multipliers matrix can be expressed as,

$$
A(1)=\left(\begin{array}{cccc}
a_{11}(1) & 0 & 0 & 0 \\
a_{21}(1) & a_{22}(1) & 0 & 0 \\
a_{31}(1) & a_{32}(1) & a_{33}(1) & 0 \\
a_{41}(1) & a_{42}(1) & a_{43}(1) & a_{44}(1)
\end{array}\right)
$$

The reduced form of the VAR model in equation (2) can be estimated by using Ordinary Least Square (OLS) method. The number of lags was determined by choosing the lowest value of the Akaike Information Criterion. All the $z_{t}$ variables in equation (2) were expressed in $\log$ and in first difference form. Once the reduced form the VAR model was estimated, the contemporaneous effect of $e_{t}$ on $z_{t}$ can be recognised. The matrix $A_{0}$ is then constructed through:

$\Sigma_{u}=A_{0} \mathrm{~A}_{0}^{\prime}$

The matrix $A_{0}$ was used to obtain $A_{i}$ from $A^{-1}{ }_{0} A_{i}=B_{i}$, where $i=1,2, \ldots$. On the other hand, $e_{t}$ can be obtained from $u_{t}=A^{-1} e_{i}$. Once $A_{0}$ and $e_{t}$ were estimated, the time series of exogenous shocks were obtained in terms of the moving average representations as showed in equation (3). From the moving average, the impact of the exogenous oil price shocks to the endogenous variables, namely output, exchange rates and price levels in the system can be calculated through the impulse response functions and the variance decompositions. 


\section{DATA}

This study covers the period from 1980 to 2005, based on the monthly time series data. The flexible exchange rate period in Malaysia extends from January 1980 to December 1997; the fixed exchange rate period was in evidence between January 1999 and June 2005. Exchange rate regime in Malaysia is classified as the fixed exchange rate regime when Malaysian Ringgit was pegged to the United States Dollar. On the other hand, the floating exchange rate regime is in evidence when the Malaysian currency exchange rate was tied to a basket of the major trading partners' currencies.

The source of data were various issues of International Financial Statistics, published by the International Monetary Fund.

In line with Abeysinghe's (2001) study, the real oil price, $o i l_{t}$, was defined as,

$$
\text { oil }_{t}=\log \left[O I L_{t}\left(\frac{N E R_{t}}{P_{t}^{M}}\right)\right]
$$

where $O I L_{t}$ is the world oil prices designated in the United States Dollar per barrel; $N E R_{t}$ is the exchange rate of Malaysian Ringgit per one unit of the United States Dollar; and $P_{t}^{M}$ is Malaysian consumer price index (CPI).

Specification of the oil prices allows for possible symmetric and asymmetric effects due to the positive and negative price changes (Mork, 1989; Mork, et al., 1994).

The relative price levels in different countries were measured by the exchange rates. The real exchange rate, rer $_{t}$, was defined as,

$\operatorname{rer}_{t}=\log \left[N E R_{t}\left(\frac{P_{t}^{U S}}{P_{t}^{M}}\right)\right]$

where $N E R_{t}$ is the nominal exchange rate of a unit of domestic currency per a unit of foreign currency; $P_{t}^{U S}$ and $P_{t}^{M}$ are the foreign and the domestic price levels, respectively.

\section{RESULTS}

Before this paper examines the insulating properties of the different exchange regimes, it a preliminary analysis of the stochastic property of the time series data is presented. First of all, the ADF test was used to examine the stationarity of the time series data. The optimal lag length, $n$, for the ADF test was chosen by minimising the Akaike's Information Criterion.

Table 1 reports the empirical findings from three different specifications of ADF regression model, i.e., 1) without constant and without time trend, $\delta ; 2)$ with a constant, $\delta_{C} ; 3$ ) with a constant and time trend, $\delta_{c, t}$.

By comparing the calculated test statistics with MacKinnon's (1996) critical values, the null hypothesis of non-stationarity cannot be rejected in levels for all the variables. However, the null hypothesis can be rejected in the first difference. As reported in Table 1, the obtained results indicated that all the variables - oil, $y$, reer and $p$ - have unit roots in levels. This means that both time series become stationary in the first difference. In other words, all variables are integrated of order one, I(1).

In the second stage of the preliminary analysis of the stochastic property, Johansen cointegration test was used to test the long-run movement of the variables. According to Engle and Granger (1987), only variables with the same order of integration can be subject to cointegration analysis. Therefore, in the present study, all the variables could be examined for cointegration. The Akaike Information Criterion was used to determine the optimal lag length selection, while the maximum lag length was set for two (2).

Both the maximum eigenvalue test statistics and the trace test statistics indicated the lack of existence of a cointegrating relationship between the variables (i.e., oil, $y$, reer, and $p$ ). This means that there is no long-run relationship between these four variables. In other words, although the four variables were non-stationary in levels and stationary in the first difference, in the long-run, they do not move closely with each other (Table 2). 
Table 1

Unit Root Tests

\begin{tabular}{llll}
\hline Variable & \multicolumn{1}{c}{$\delta$} & \multicolumn{1}{c}{$\delta_{\mathrm{c}}$} & \multicolumn{1}{c}{$\delta_{\mathrm{c}, \mathrm{t}}$} \\
\hline oil & $-1.5937(4)$ & $-1.6880(4)$ & $-1.0245(6)$ \\
$y$ & $2.4061(15)$ & $-0.9250(15)$ & $-2.8794(13)$ \\
reer & $-1.1189(9)$ & $-0.9334(9)$ & $-2.7798(9)$ \\
$P$ & $2.6832(13)$ & $-0.4216(13)$ & $-2.4284(13)$ \\
$\Delta$ oil & $-8.7988(5)^{* *}$ & $-8.7843(5)^{* *}$ & $-9.1318(5)^{* *}$ \\
$\Delta y$ & $-3.2760(12)^{* *}$ & $-4.3883(14)^{* *}$ & $-4.4075(14)^{* *}$ \\
$\Delta$ ireer & $-5.0385(8)^{* *}$ & $-5.1543(8)^{* *}$ & $-5.1488(8)^{* *}$ \\
$\Delta_{i p}$ & $-2.5599(12)^{*}$ & $-3.6952(12)^{* *}$ & $-3.4651(13)^{*}$ \\
\hline
\end{tabular}

Note: $*$ denotes $5 \%$ significance level

** denotes $1 \%$ significance level

Figures in parentheses indicate number of lag structures

Table 2

Johansen Cointegration Tests

\begin{tabular}{llcclcc}
\hline $\mathrm{H}_{0}$ & Eigenvalue & $\lambda_{\text {Trance }}$ & $\begin{array}{c}\text { Critical } \\
\text { value }\end{array}$ & Eigenvalue & $\lambda_{\text {Max }}$ & Critical value \\
\hline$r=0$ & 0.0550 & 40.9170 & 47.8561 & 0.0550 & 17.1434 & 27.5843 \\
$r \leq 1$ & 0.0473 & 23.7736 & 29.7971 & 0.0473 & 14.6677 & 21.1316 \\
$r \leq 2$ & 0.0190 & 9.1059 & 15.4947 & 0.0190 & 5.8132 & 14.2646 \\
$r \leq 3$ & 0.0108 & 3.2927 & 3.8415 & 0.0108 & 3.2927 & 3.8415 \\
\hline
\end{tabular}

Note: The result corresponds to VAR's with two lags (no signs $* * *$ in the table?)

Next, this study proceeded to examine the insulation property of different exchange rate regimes. The Akaike Information Criterion was used again to determine the optimal lag length in the VAR model. According to this criterion, the lag length is set for two (2) which minimises the Akaike Information Criterion. Figure 1 shows the adjustment process of real exchange rates, price levels, and index of industrial production in response to the changes in the oil prices under the two different exchange rate regimes. Figure 1(a) indicates that there are more fluctuations in responses of real exchange rates to the oil price shocks under the fixed exchange rate regime. On the other hand, the responses of real exchange rates under the flexible exchange rate regime oscillate less.

As Figure 1(b) indicates, the response of CPI to oil price shocks under the flexible exchange rate regime took a shorter time to restore the equilibrium by moving back to the original position. On the other hand, the process required a longer time span under the fixed exchange rate regime.

Finally, Figure 1(c) indicates that the volatility of output in response to oil price shocks was much higher under the fixed exchange rate regime. Furthermore, the responses took a longer 
time to move back the original position. Under the flexible exchange rate regime, there were fewer

Flexible

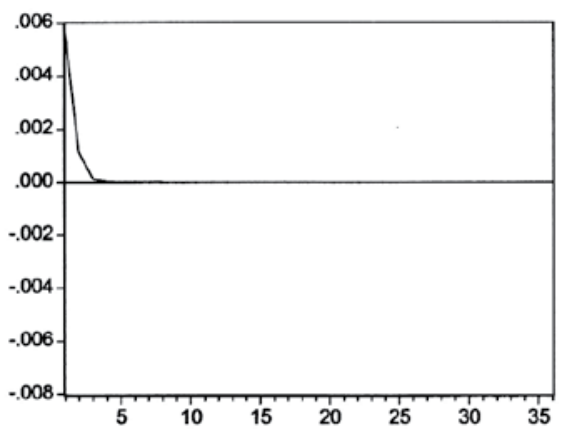

Figure 1a: Responses of real exchange rates

Flexible

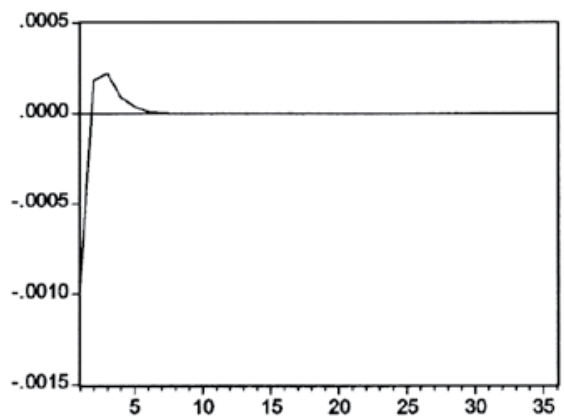

Figure 1b: Responses of CPI

Flexible

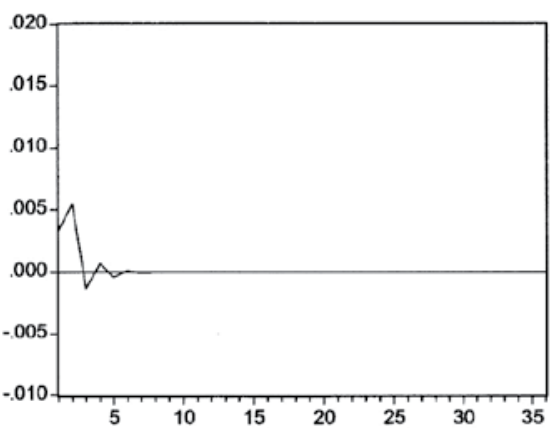

Figure 1c: Responses of output fluctuations, and the responses required a shorter time span to move back to the original position.

Fixed

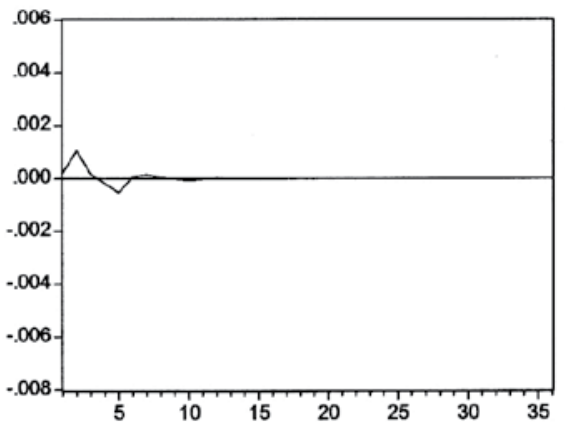

Fixed

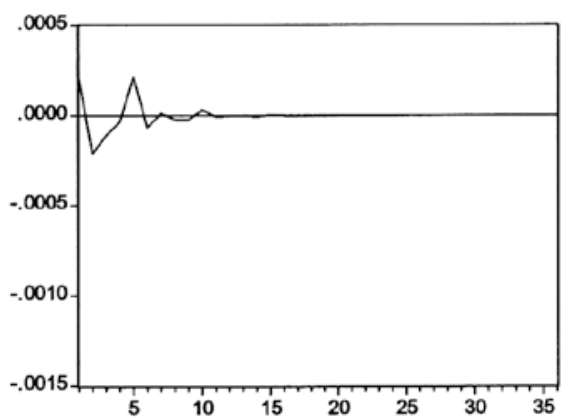

Fixed

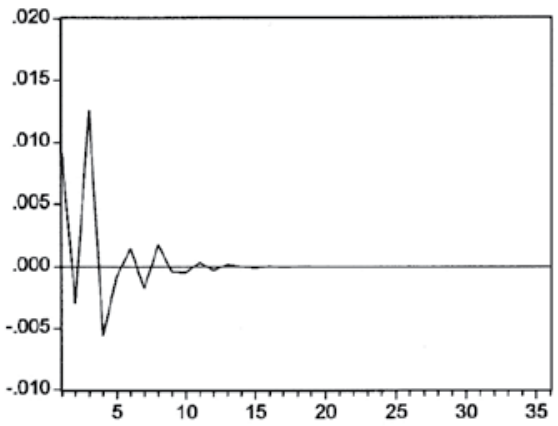

Figure 1

Respondes to Oil Price Shock 
These results supported Friedman's (1953) hypothesis. In other words, the findings of the present study provided empirical evidence to support a proposition that the flexible exchange rate regime can ensure a smoother adjustment process to the foreign-originated economic shocks, such as the oil price shocks.

Table 3

Variance Decompositions of Domestic Variables

\begin{tabular}{clllccc}
\hline \multirow{2}{*}{ Months } & \multicolumn{3}{c}{ Flexible } & & \multicolumn{3}{c}{ Fixed } \\
\cline { 2 - 6 } & rer & $\mathrm{p}$ & $\mathrm{y}$ & rer & $\mathrm{p}$ & $\mathrm{y}$ \\
\hline 1 & 14.1147 & 5.5196 & 0.2594 & 0.3783 & 0.7131 & 6.8936 \\
2 & 11.2949 & 5.3365 & 0.7603 & 7.5416 & 1.4466 & 4.6441 \\
3 & 10.5045 & 5.5817 & 0.7600 & 7.1433 & 1.5748 & 11.1330 \\
6 & 10.1647 & 5.6252 & 0.7636 & 8.2396 & 2.3105 & 11.7917 \\
9 & 10.1534 & 5.6250 & 0.7637 & 8.3302 & 2.3224 & 11.9572 \\
12 & 10.1530 & 5.6249 & 0.7637 & 8.3584 & 2.3383 & 11.9598 \\
24 & 10.1529 & 5.6249 & 0.7637 & 8.3589 & 2.3390 & 11.9610 \\
36 & 10.1529 & 5.6249 & 0.7637 & 8.3589 & 2.3390 & 11.9610 \\
\hline
\end{tabular}

For the next step, this study measured the relative importance of the oil price shocks on the overall variance of domestic macroeconomic variables. Table 3 reports the relative importance of oil price disturbances in explaining the overall variance of real exchange rates, price levels, and output across the exchange rate regimes. As the findings show, the oil price innovation accounted for a higher fraction of variance in real exchange rates under the flexible exchange rate regime compared to the fixed exchange rate regime. This means that under the flexible exchange rate regime, oil price shock was key in explaining the changes of real exchange rates relative to the volatility of price levels and alterations in the exchange rates.

In other words, oil price shocks can be better absorbed under the flexible exchange rate regime than under the fixed exchange rate regime. Under the fixed exchange rate regime, the contribution of the oil price shocks is primary in explaining the volatility of output. Thus, the importance of the oil price shocks in explaining the changes in price levels is greater under the flexible exchange rate regime than under fixed exchange regime. Overall, the results of the variance decomposition confirmed the validity of Friedman's (1953) hypothesis regarding the effectiveness of the flexible exchange rate regime in absorbing oil price shocks.

\section{CONCLUSION}

Friedman (1953) suggested that nominal exchange rates could be used to insulate an economy from external shocks. The exchange rate matters due to the presence of "stickiness" in the price adjustment process. The empirical findings of the current study seem to confirm this famous Friedman's hypothesis. 
First of all, the current inquiry found that macroeconomic variables have less volatile response to oil price shocks under the flexible exchange rate regime compared to the fixed exchange rate regime. This means that the flexible exchange rate regime can ensure a much smoother response to oil price shocks. Furthermore, the responses of price levels to the oil price shocks are also smoother under the flexible exchange rate regime.

The results of variance decomposition consistently confirmed the validity of Friedman's hypothesis regarding the effectiveness of the flexible exchange rate regime in absorbing oil price shocks. The findings of this study highlighted some possible directions of future research on this interesting topic. For example, future studies could focus on responses of macroeconomic variables to internal economic shocks, such as the demand shock and the supply shock. This would give a deeper insight into the complex nature of economic landscape in Malaysia.

\section{REFERENCES}

Abeysinghe, T. (2001). Estimation of direct and indirect impact of oil price on growth. Economics Letters, 73(2), 147-153.

Baxter, M., \& Stockman, A. (1989). Business cycles and the exchange-rate regime: Some international evidence. Journal of Monetary Economics, 23(3), 377-400.

Bayoumi, T., \& Eichengreen, B. (1994). Macroeconomic adjustment under Bretton Woods and the post-Bretton Woods float: An impulse-response analysis. The Economic Journal, 104(425), 813-827.

Blanchard, O. J., \& Quah, D. (1989). The dynamic effects of aggregate demand and supply disturbances. The American Economic Review, 79(4), 655-673.

Broda, C. (2004). Terms of trade and exchange rate regimes in developing countries.
Journal of International Economics, 63(1), 31-58.

Burbidge, J., \& Harrison, A. (1984). Testing for the effects of oil-price rises using vector autoregressions. International Economic Review, 25(2), 459-484.

Chua, S. Y., Dibooglu, S., \& Sharma, S. C. (1999). The impact of the US and Japanese economies on Korea and Malaysia after the Plaza Accord. Asian Economic Journal, 13(1), 19-37.

Cunado, J., \& Gracia, F. P. (2005). Oil prices, economic activity and inflation: Evidence for some Asian countries. The Quarterly Review of Economics and Finance, 45(1), 65-83.

Dickey, D. A., \& Fuller, W. A. (1981). Likelihood ratio statistics for autoregressive time series with a unit root. Econometrica, 49(4), 1057-1072.

Engle R., \& Granger, C. (1987). Co-integration and error correction: Representation, estimation and testing. Econometrica, 55(2), 251-276.

Edwards, S., \& Levy Yeyati, E. (2005). Flexible exchange rates as shock absorbers. European Economic Review, 49(8), 2079-2105.

Ferderer, J. P. (1996). Oil price volatility and the macroeconomy. Journal of Macroeconomics, 18(1), 1-26.

Friedman, M. (1953). Essays in positive economics. Chicago: University of Chicago.

Genberg, H., Salemi, M. K., \& Swoboda, A. (1987). The relative importance of foreign and domestic disturbances for aggregate fluctuations in the open economy: Switzerland, 1964-1981. Journal of Monetary Economics, 19(1), 45-67. 
Gerlach, H. M. S. (1988). World business cycles under fixed and flexible exchange rates. Journal of Money, Credit, and Banking, 20(4), 621-632.

Gisser, M., \& Goodwin, T. H. (1986). Crude oil and the macroeconomy: Tests of some popular notions. Journal of Money, Credit, and Banking, 18(1), 95-103.

Guo, H., \& Kliesen, K. L. (2005). Oil price volatility and U.S. macroeconomic activity. Federal Reserve Bank of St. Louis Review, 87(6), 669-683.

Hamilton, J. D. (1983). Oil and the macroeconomy since World War II. The Journal of Political Economy, 91(2), 228-248.

Hamilton, J. D. (1996). This is what happened to the oil price - macroeconomy relationship. Journal of Monetary Economics, 38(2), 215-220.

Hoffmaister, A.W., Roldós, J.E., \& Wickham, P. (1997). Macroeconomic fluctuations in Sub-Saharan Africa. (IMF Working Paper No. WP/97/82). Washington: International Monetary Fund.

Hooker, M.A. (1996). What happened to the Oil Price - macroeconomy relationship? Journal of Monetary Economics, 38(2), 195-213.

Hutchison, M., \& Walsh, C. E. (1992). Empirical evidence on the insulation properties of fixed and flexible exchange rates: The Japanese experience. Journal of International Economics, 32(3/4), 241263.

The International Monetary Fund. Various issues. International Financial Statistics. Washington: International Monetary Fund.

Johansen, S. (1991). Estimation and hypothesis testing of cointegration vectors in Gaussian vector autoregressive models. Econometrica, 59(6), 1551-1580.
Lastrapes, W. D., \& Koray, F. (1990). International transmission of aggregate shocks under fixed and flexible exchange rate regimes: United Kingdom, France, and Germany, 1959 to 1985. Journal of International Money and Finance, 9(4), 402-423.

Lee, K. S, Ni., S., \& Ratti, R. A. (1995). Oil shocks and the macroeconomy: The Role of price variability. Energy Journal, 16(4), 39-56.

MacKinnon, J. G. (1996). Numerical distribution functions for unit root and cointegration tests. Journal of Applied Econometrics, 11(6), 601-618.

Mansor, H. I. (2003). International disturbances and domestic macroeconomic fluctuations in Malaysia. ASEAN Economic Bulletin, 20(1), 11-30.

Mork, K. A. (1989). Oil and the macroeconomy when prices go up and Down: An extension of Hamilton's results. The Journal of Political Economy, 97(3), 740-744.

Mork, K. A., Olsen, O., \& Mysen, H. T. (1994). Macroeconomic responses to oil price increases and decreases in seven OECD countries. Energy Journal, 15(4), 19-35.

Ramcharan, R. (2005). Cataclysms and currencies: Does the exchange rate regime matter for real shocks? (IMF Working Paper No. WP/05/85). Washington: International Monetary Fund.

Robertson, D., \& Wickens, M. R. (1997). Measuring real and nominal macroeconomic shocks and their international transmission under different monetary systems. Oxford Bulletin of Economics and Statistics, 59(1), 5-27.

Sims, C. A. (1980). Macroeconomics and reality. Econometrica, 48(1), 1-48.

Sissoko, Y., \& Dibooglu, S. (2006). The exchange rate system and macroeconomic fluctuations in Sub-Saharan Africa. Economic Systems, 30(2), 141-156. 